Scientific Journal Warsaw University of Life Sciences - SGGW

Problems of World Agriculture volume 17 (XXXII), number 4, 2017: 236-248

DOI: 10.22630/PRS.2017.17.4.100

\author{
Karolina Pawlak ${ }^{1}$ \\ Poznań University of Life Sciences
}

\title{
Importance and Comparative Advantages of the EU and US Agri-food Sector in World Trade in 1995-2015 ${ }^{2}$
}

\begin{abstract}
The aim of the paper was to examine the evolution of the importance and comparative advantages of the EU and US agri-food sector in world trade in 1995-2015. The research is based on data from UNCTAD (United Nations Conference on Trade and Development) resources. The following indicators were used in the comparative advantage analysis: Balassa's Revealed Comparative Advantage (RCA), Vollrath's Revealed Competitiveness (RC), the Revealed Symmetric Comparative Advantage (RSCA), and the Lafay's Trade Balance Index (TBI). In 1995-2015, the EU countries and the US were the largest players of world trade in agri-food products. The EU countries held comparative advantages in the global market as regards exports of products of animal origin whereas the exports of cereals, preparations of cereals, oilseeds and oleaginous fruits and meat products were the source of revealed comparative advantages for the US. Both the EU countries and the US reached high comparative advantages in trade in those assortment groups which corresponded to their highest shares in global exports and generated a high, consistently increasing positive trade balance. Therefore, their comparative advantages were the source of their favourable export specialisation profile, which is consistent with the classical comparative costs principle.
\end{abstract}

Key words: international competitiveness, comparative advantages, export specialisation, agri-food products, world trade, the EU, the US

JEL Classification: F10, F14, Q17

\section{Introduction}

Today's world economy experiences two contradictory trends. On one hand, as a consequence of progressing globalisation and regional economic integration processes, trade is well on its way to comply with the free trade concept advanced by classical economists. On the other hand, however, there are protectionist trends emerging gradually as a counter-reaction to the international trade liberalisation processes and to the increasing competitive capacity of new industrialized countries (Rynarzewski and Zielińska-Głębocka, 2006). The free market and free trade mechanisms contribute to the openness of national economies, make them more focused on international trade and contribute to the increased importance of international competitiveness ${ }^{3}$.

By referring to the line of research on international competitiveness which is rooted in international exchange theories and emphasizes the importance of free trade (Kim and

\footnotetext{
${ }^{1}$ Doctor habilitated, professor of the PULS, Department of Economics and Economy Policy in Agribusiness, Poznań University of Life Sciences, ul. Wojska Polskiego 28, 60-637 Poznań, e-mail: pawlak@up.poznan.pl https://orcid.org/0000-0002-5441-6381

${ }^{2}$ The paper is funded by National Science Centre within the OPUS research project No. 2015/17/B/HS4/00262, titled „Polish agri-food sector under the implementation of the Transatlantic Trade and Investment Partnership agreement (TTIP)".

${ }^{3}$ This is particularly true for economies affected by insufficient effective demand (referred to as "demandrestricted economies").
} 
Marion, 1997), international competitiveness may be defined as the "ability to maintain or increase the market shares" (Agriculture Canada, 1991; van Duren, Martin and Westgren, 1991; Kennedy et al., 1997; Pitts and Lagnevik, 1998). The simplest, but not flawless, indicators of international competitiveness levels include the trade balance and shares in world trade 4 . Assuming that in the era of internationalisation and globalisation of many industries, competitiveness may only be assessed in the context of international markets (Stanowisko Rady Strategii..., 1997; Wziątek-Kubiak, 2003), the "domestic companies' ability to effectively and profitably establish their operations in international markets and develop effective exports" (Woś, 2001) became one of the priorities of economic policies adopted by many countries and is determined through those policies.

In 1990-2015, affected by the changing macroeconomic and institutional conditions, the shares of specific countries and continents in world trade developed dynamically, reflecting their changing economic standing. In this period, the European and North American countries were among those experiencing a decline in their economic activity. In 2016, their share in global exports (compared to 1990) decreased by 14 and 3 percentage points, respectively, reaching $37 \%$ and $14 \%$ (WTO, 2017). One reason for this was the 2007-2009 worldwide economic crisis manifested by a decline in the trade volume in 20082009 , disproportionately high compared to the reduction of demand ${ }^{5}$. Under these circumstances, the importance of competition theory and policy was recognized once again. A discussion was initiated on the sources of advantage of one economy over another. Also, attempts were made to quantify the competitive advantages of specific countries or sectors of their national economies.

The EU and the US are the largest players of world trade in agri-food products. Today, agricultural goods are traded increasingly often between countries at similar levels of economic development with similar access to production factors, mostly on an intraindustry basis. Also, agricultural raw materials and foodstuffs are considered to be heterogeneous rather than homogenous goods. With the above in mind, modern trade theories play an increasingly important role in explaining the sources of benefits from trade and competitive advantages over partners. According to these theories, trade flows are determined by such factors as changes in access to production factors; changes in manufacturing efficiency in and between specific countries; increase of disposable incomes per capita; transport costs; national economic policies; ability to achieve economies of scale of production and sale; differentiation in levels of technological progress between countries, affecting product diversification and lifecycle ${ }^{6}$. Despite the increasing importance of the above factors, the proper development of agricultural trade flows and structure and the international competitiveness of the agri-food sector may also be

\footnotetext{
4 According to Casson (1991), a positive trade balance means an advantageous commodity structure and favourable trade conditions. The generated surplus usually results from the increased efficiency of trade which largely depends on the competitiveness of domestic products (Hybel, 2002). Therefore, despite some methodological doubts (Krugman, 1994), the trade balance is a reliable indicator of competitiveness which becomes increasingly important as the period under consideration grows longer (Bieńkowski, 1995).

${ }^{5}$ According to JaeBin, Amiti and Weinstein (2011), during the last economic downturn, international trade flows were three times more sensitive to the reduction of global demand than GDP. Also, in their analysis of the US economy, Levchenko, Lewis and Tesar (2010) demonstrate that the decrease of the trade to GDP ratio was the highest in 60 years. For a broader discussion on reasons behind the strengthened erosion of trade during the 20072009 economic crisis, see Czarny and Śledziewska (2012).

${ }^{6}$ For a broader discussion on sources of competitive advantages in modern international trade theories, see Pawlak (2013).
} 
considered as the effect of comparative advantages, in line with the foreign trade models by Ricardo and Heckscher, Ohlin and Samuelson. This is because according to a study by Pawlak (2013), the higher technical potential of the EU-15 farms provides these countries with a comparative advantage primarily as regards capital-intensive production profiles dependent upon technical progress. In turn, the Central and Eastern European agriculture has an advantage in labour-intensive production profiles. Note also that countries with a temperate climate usually generate a higher comparative advantage in the trading of products of animal origin whereas Mediterranean countries tend to run the specialisation and earn their profits from exports of plant products.

The development of new trade theories is without detriment to the classical concept of comparative advantages. However, in view of dynamic changes taking place in national economies and in the world economy, it was realized that while no country has a guaranteed, sustainable competitive advantage, the ability to compete in the long run is important from the perspective of setting policy priorities 7 . In that context, the objective of this study was formulated which is to examine the evolution of the importance and comparative advantages of the EU and US agri-food sector in world trade in 1995-2015.

\section{Data and methods}

This study relies on data from UNCTAD (United Nations Conference on Trade and Development) resources. To identify the evolution of the importance of the $\mathrm{EU}^{8}$ and US in world agri-food trade, the analysis covered the value, balance and growth rate of trade and the shares of the countries considered in global exports and imports.

The following indicators were used in the comparative advantage analysis: Balassa's Revealed Comparative Advantage (RCA), Vollrath's Revealed Competitiveness (RC), the Revealed Symmetric Comparative Advantage (RSCA) as per the formula proposed by Laursen and Dalum et al., and the Lafay's Trade Balance Index (TBI).

The Balassa's Revealed Comparative Advantage (RCA) is the ratio between the share of exports of a product in world trade and the share of exports of the entire sector in world trade (Balassa, 1965):

$$
\operatorname{RCA}_{\mathrm{ij}}=\mathrm{RXA}_{\mathrm{ij}}=\left(\mathrm{X}_{\mathrm{ij}} / \mathrm{X}_{\mathrm{ik}}\right) /\left(\mathrm{X}_{\mathrm{nj}} / \mathrm{X}_{\mathrm{nk}}\right)
$$

with: $X$ - exports, $i-$ country under consideration, $j$ - product (product group) under consideration, $k$ - all goods, $n$ - reference country (countries).

If above one, RCA means a favorable competitive situation. Lower values demonstrate the absence of comparative advantages (Balassa, 1965; Peterson, 1988). In this form, RCA was used to assess the competitive position of the agri-food sector by many researchers, including Anderson (1990), Leishman, Menkhaus and Whipple (1999) and Banterle (2005). The weakness of the Balassa's index is that the comparative advantages are estimated based solely on the value of exports. A more comprehensive approach to the analysis of

\footnotetext{
${ }^{7}$ The dynamic nature of competitiveness was already noted by Porter (1990) and Landau (1992), and the dynamics of comparative advantages were analysed by Vollrath (1985).

${ }^{8}$ In order to ensure an objective (undistorted by subsequent enlargements of the EU) assessment of changes over time, the EU was treated as a group of 28 member states during the entire period under consideration.
} 
comparative advantages, taking both the import and export performance of a country into consideration, was proposed by Vollrath (1989) who developed the Revealed Competitiveness $(\mathrm{RC})$ index which is the difference between natural logarithms of the revealed comparative advantage in exports $(\mathrm{RCA}=\mathrm{RXA})$ and of the revealed comparative advantage in imports (RMA, calculated similarly):

$$
\mathrm{RC}_{\mathrm{ij}}=\ln \left(\mathrm{RXA}_{\mathrm{ij}}\right)-\ln \left(\mathrm{RMA}_{\mathrm{ij}}\right)
$$

Positive $\mathrm{RC}$ values indicate the existence of a competitive advantage whereas negative values mean an unfavourable competitive situation. The competitive position of agri-food products was estimated with the use of the Vollrath's modified indexes of revealed comparative advantage by many researchers, including Bojnec (2001), Rytko (2003), Banterle and Carraresi (2007), as well as Pawlak and Poczta (2011).

Because of the asymmetric distribution and the absence of a finite upper limit of RCA, several modified formulas were developed with a symmetric distribution (Posłuszny, 2011). Laursen (1998) and Dalum et al. (1998) adjusted the RCA, enabling the definition of Revealed Symmetric Comparative Advantages (RSCA), calculated as follows:

$$
\operatorname{RSCA}_{\mathrm{ij}}=\left(\mathrm{RCA}_{\mathrm{ij}}-1\right) /\left(\mathrm{RCA}_{\mathrm{ij}}+1\right)
$$

RSCA falls into the interval $[-1,1]$ with negative and positive values indicating, respectively, the absence and existence of a comparative advantage. De Benedictis and Tamberi (2002) claim that the above transformation of the Balassa's index does not provide any benefits in terms of interpretation. However, when combined with the Lafay's Trade Balance Index (TBI), it may enable the creation of a matrix to synthetically assess the competitive position of specific countries trading in specific products or product groups in selected reference markets (Widodo, 2009). TBI falls into the interval $[-1,1]$ and may be determined as follows (Lafay, 1992):

$$
\mathrm{TBI}_{\mathrm{ij}}=\left(\mathrm{X}_{\mathrm{ij}}-\mathrm{M}_{\mathrm{ij}}\right) /\left(\mathrm{X}_{\mathrm{ij}}+\mathrm{M}_{\mathrm{ij}}\right)
$$

Positive values indicate a specialized country and usually mean a trade surplus, whereas negative values are characteristic of countries with no export specialisation which are net importers of the product or product group concerned. Considering the RSCA and TBI values, Widodo (2009) developed a matrix enabling the identification of four competitive position scenarios for a country, depending on the level of its comparative advantages and on the level of its export specialisation (Fig. 1) ${ }^{9}$.

In this study, the product mapping schemes were developed for two research periods: 1995-1997 and 2013-2015. The applied methodological approach allowed to assess the long-run ability of the EU and US agri-food sector to compete in global trade and to answer the following questions: Did changes in the trade commodity structure in these countries appear in accordance with the principle of comparative costs? Is it possible to consider them as rational from this point of view? Such an analysis gives grounds for making some

\footnotetext{
${ }^{9}$ This product mapping scheme was used by many researchers, including Ervani (2013), Ishchukova and Smutka
} (2014) and Benesova et al. (2017), in their studies on the international competitiveness of the agri-food sector. 
recommendations regarding the potential reorientation of the trade commodity structure due to their comparative advantages being the source of their favourable export specialisation.

\begin{tabular}{|c|c|}
\hline $\begin{array}{c}\text { Group B: } \\
\text { Comparative advantage } \\
\text { Net-importer } \\
(\text { RSCA }>0 \text { and } \mathrm{TBI}<0)\end{array}$ & $\begin{array}{c}\text { Group A: } \\
\text { Comparative advantage } \\
\text { Net-exporter } \\
(\text { RSCA }>0 \text { and } \mathrm{TBI}>0)\end{array}$ \\
\hline $\begin{array}{c}\text { Group D: } \\
\text { Comparative disadvantage } \\
\text { Net-importer } \\
(\mathrm{RSCA}<0 \text { and } \mathrm{TBI}<0)\end{array}$ & $\begin{array}{c}\text { Group C: } \\
\text { Comparative disadvantage } \\
\text { Net-exporter } \\
(\text { RSCA }<0 \text { and } \mathrm{TBI}>0)\end{array}$ \\
\hline
\end{tabular}

$\mathrm{TBI}<0$

$\mathrm{TBI}>0$

Fig. 1. Product mapping scheme based on the level of comparative advantage and export specialisation by Widodo Source: Widodo (2009).

Comparative advantages were analyzed at the level of product groups identified in line with the Standard International Trade Classification (SITC). The timeframes of this study were determined by the availability of complete essential data comparable on an international basis.

\section{Value of trade and the EU and US share in world trade in agri-food products}

In 1995-2015, as the globalisation of the world economy and regional economical integration processes were progressing, there was a boost in the global agri-food trade. The world's largest agri-food exporter were the EU countries which accounted for approximately $39 \%$ of the global exports in mid-2010s, generating an annual revenue of around USD 553 billion (in 2013-2015). Note however that the trade with non-EU countries (at an average annual level of USD 146 billion in 2013-2015) represented slightly more than $1 / 4$ of the total agri-food exports in this group of countries. This means a share of only slightly more than 10 percent in the world exports, a result comparable to that of the US (Table 1). The high share of intra-EU flows in the EU's agricultural exports is determined by similar consumption patterns and food marketing systems (Reed, 2001), in addition to geographic proximity and absence of mutual trade barriers. In 2013-2015, with an average annual value of exports of USD 141 billion, the US were the world's second largest exporter of agri-food products. Notably, in 1995-2015, the growth rate of agri-food exports from the EU and US was below the world average, resulting in a decrease of their shares in the global exports by 6 percentage points and around 3 percentage points, respectively.

Similar trends were observed for all key assortment groups in the structure of the EU and US agri-food exports. In mid-2010s, the EU countries were the origin of approximately $60 \%$ of the world's exports of dairy products and livestock; $45 \%$ of exported meat and meat preparations; over $1 / 3$ of the global export of cereals and preparations of cereals, as well as 
fruit and vegetables; nearly $30 \%$ of the world's exports of sugar and sugar confectionery, oils and fats. Note that despite the dynamic growth of the absolute value of exports, during the last two decades, the importance of the EU countries as providers of the above assortment groups to the global market has consistently reduced, especially when it comes to more processed animal products, horticultural products, sugar and sugar confectionery (Table 1). In third countries, the position of the EU countries as exporters of the latter group and of dairy products has considerably weakened. In 2013-2015, following a decline by nearly 13 percentage points and over 10 percentage points, respectively, the international sales of these two product groups in non-EU markets represented less than $6 \%$ and slightly above $15 \%$ of the world's exports. Note also that when considering only the trade flows with third countries, the EU's share in the world's exports of the aforesaid product groups was no more than $11 \%$. Meanwhile, the US have reduced their share in the global sales of cereals and oilseeds. In 2013-2015, the exports of these assortment groups from the US represented, respectively, around $14 \%$ and $30 \%$ of the global exports, compared to $26 \%$ and $47 \%$ in 1995-1997. Even though their importance in world trade has declined, the US export more cereals, oilseeds, fruits, vegetables, meat and meat preparations than the EU to third countries.

Conversely, in 1995-2015, the US increased their importance as an importer of agrifood products (Table 1). Eventually, in mid-2010s, compared to EU and its trade relationships with third countries, the US imported more animal products, cereals, preparations of cereals, sugar and sugar confectionery, while having a smaller share in the global imports of oils and fats, oilseeds and oleaginous fruits, fruit and vegetables, which are produced in surplus quantities in the US and are traditionally exported because of the cost and price advantages. Due to high level of food self-sufficiency, only small volumes of animal products and cereals were imported to the EU from third countries. These goods were mainly traded inside the EU and, considering the entire trade volume, allowed the EU countries to reach a share of more than 25 percent in the global imports of cereals and preparations of cereals, and a share of around 45 percent in the imports of animal products. The EU countries' share in the global imports of fruit and vegetables was at a similar level. Also, they had a share of around $30 \%$ in the global imports of sugar, sugar confectionery, oils and fats, and a share of $20 \%$ in the global imports of oilseeds and oleaginous fruits.

In 2013-2015, the average total value of agri-food imports to the EU, both from the Single European Market and from third countries, following a two-and-a-half times increase in the 1995-2015 period, was nearly USD 540 billion per year and represented almost $38 \%$ of the world's import volume (Table 1). During that period, the value of agrifood imports to the US more than tripled. In 2013-2015, food imports to the American market absorbed more than USD 130 billion per year, representing approximately $9 \%$ of global imports. What should be noted is that even though the imports grew faster than the exports, the US remained a net exporter of all key products in the exports structure except for fruit and vegetables while experiencing a significant improvement in the trade balance for meat, meat preparations, dairy products, oilseeds and oleaginous fruits. The EU countries, due to the need to import products from other climate zones, have become an increasingly important net importer of oilseeds, oils, fats, fruit and vegetables in the global market while reporting a growing surplus of trade in animal origin products and cereals. 
Table 1. Value of trade and the EU and US share in world trade in agri-food products in 1995-1997 and 2013-2015

\begin{tabular}{|c|c|c|c|c|c|c|c|c|c|c|c|c|}
\hline \multirow{3}{*}{ Product group } & \multicolumn{3}{|c|}{ Exports } & \multicolumn{2}{|c|}{$\begin{array}{l}\text { Share in the } \\
\text { world exports }\end{array}$} & \multicolumn{3}{|c|}{ Imports } & \multicolumn{2}{|c|}{$\begin{array}{l}\text { Share in the } \\
\text { world imports }\end{array}$} & \multicolumn{2}{|c|}{ Trade balance } \\
\hline & $\begin{array}{l}1995- \\
1997\end{array}$ & \multicolumn{2}{|c|}{ 2013-2015 } & \multirow{2}{*}{\multicolumn{2}{|c|}{$\begin{array}{cc}1995- & 2013- \\
1997 & 2015 \\
& \\
& \%\end{array}$}} & $\begin{array}{c}1995- \\
1997\end{array}$ & \multicolumn{2}{|c|}{ 2013-2015 } & \multicolumn{2}{|c|}{$\begin{array}{ll}1995- & 2013- \\
1997 & 2015\end{array}$} & $\begin{array}{l}1995- \\
1997\end{array}$ & $\begin{array}{l}2013- \\
2015\end{array}$ \\
\hline & \multicolumn{3}{|c|}{ Million USD } & & & Millior & USD & $1995=100$ & $\%$ & & Millio & USD \\
\hline \multicolumn{13}{|c|}{ EU in total } \\
\hline Live animals & 5737 & 13025 & 227.0 & 55.9 & 59.3 & 4739 & 9766 & 206.1 & 46.7 & 44.0 & 998 & 3259 \\
\hline $\begin{array}{l}\text { Meat and meat } \\
\text { preparations }\end{array}$ & 27538 & 65487 & 237.8 & 56.2 & 45.8 & 23534 & 56802 & 241.4 & 49.0 & 41.6 & 4004 & 8685 \\
\hline Dairy products & 25346 & 59025 & 232.9 & 78.0 & 63.6 & 19356 & 44121 & 228.0 & 61.0 & 48.4 & 5990 & 14903 \\
\hline $\begin{array}{l}\text { Cereals and } \\
\text { preparations of } \\
\text { cereals }\end{array}$ & 22122 & 59809 & 270.4 & 36.8 & 34.5 & 17515 & 47573 & 271.6 & 27.7 & 26.8 & 4606 & 12235 \\
\hline $\begin{array}{l}\text { Oilseeds and } \\
\text { oleaginous fruits }\end{array}$ & 1762 & 8567 & 486.2 & 11.3 & 10.6 & 7849 & 18920 & 241.0 & 46.5 & 22.0 & -6087 & -10353 \\
\hline Fruit and vegetables & 33608 & 85696 & 255.0 & 45.8 & 36.9 & 43814 & 102840 & 234.7 & 55.3 & 43.4 & -10207 & -17144 \\
\hline $\begin{array}{l}\text { Sugar and sugar } \\
\text { confectionery }\end{array}$ & 7670 & 13539 & 176.5 & 37.6 & 27.7 & 6730 & 15292 & 227.2 & 32.2 & 30.5 & 940 & -1753 \\
\hline Oils and fats & 9045 & 25784 & 285.1 & 34.0 & 27.0 & 9969 & 30780 & 308.8 & 37.1 & 31.6 & -924 & -4996 \\
\hline Total & 212076 & 552945 & 260.7 & 44.6 & 38.6 & 218689 & 539656 & 246.8 & 44.9 & 37.6 & -6613 & 13288 \\
\hline \multicolumn{13}{|c|}{$\mathrm{EU}$ - third countries } \\
\hline Live animals & 1298 & 2440 & 188.0 & 12.6 & 11.1 & 725 & 340 & 46.9 & 7.2 & 1.5 & 573 & 2099 \\
\hline $\begin{array}{l}\text { Meat and meat } \\
\text { preparations }\end{array}$ & 6205 & 11244 & 181.2 & 12.7 & 7.9 & 5739 & 7634 & 133.0 & 11.9 & 5.6 & 466 & 3610 \\
\hline Dairy products & 8279 & 14069 & 169.9 & 25.5 & 15.2 & 2697 & 1041 & 38.6 & 8.5 & 1.1 & 5582 & 13027 \\
\hline $\begin{array}{l}\text { Cereals and } \\
\text { preparations of } \\
\text { cereals }\end{array}$ & 8345 & 19084 & 228.7 & 13.9 & 11.0 & 3943 & 7892 & 200.1 & 6.2 & 4.5 & 4401 & 11192 \\
\hline $\begin{array}{l}\text { Oilseeds and } \\
\text { oleaginous fruits }\end{array}$ & 430 & 1020 & 237.0 & 2.8 & 1.3 & 6511 & 11815 & 181.5 & 38.6 & 13.8 & -6081 & -10795 \\
\hline Fruit and vegetables & 6460 & 14560 & 225.4 & 8.8 & 6.3 & 18569 & 39096 & 210.5 & 23.4 & 16.5 & -12109 & -24536 \\
\hline $\begin{array}{l}\text { Sugar and sugar } \\
\text { confectionery }\end{array}$ & 3782 & 2766 & 73.1 & 18.5 & 5.7 & 2692 & 4021 & 149.4 & 12.9 & 8.0 & 1090 & -1255 \\
\hline Oils and fats & 3244 & 6108 & 188.3 & 12.2 & 6.4 & 4397 & 12412 & 282.3 & 16.4 & 12.7 & -1153 & -6304 \\
\hline Total & 68270 & 145793 & 213.6 & 14.3 & 10.2 & 84414 & 164042 & 194.3 & 17.3 & 11.4 & -16144 & -18249 \\
\hline \multicolumn{13}{|c|}{ The US } \\
\hline Live animals & 591 & 907 & 153.5 & 5.8 & 4.1 & 1700 & 3190 & 187.6 & 16.8 & 14.4 & -1109 & -2283 \\
\hline $\begin{array}{l}\text { Meat and meat } \\
\text { preparations }\end{array}$ & 6809 & 17809 & 261.6 & 13.9 & 12.4 & 2592 & 8686 & 335.1 & 5.4 & 6.4 & 4217 & 9123 \\
\hline Dairy products & 781 & 5642 & 722.0 & 2.4 & 6.1 & 723 & 2051 & 283.7 & 2.3 & 2.3 & 58 & 3591 \\
\hline $\begin{array}{l}\text { Cereals and } \\
\text { preparations of } \\
\text { cereals }\end{array}$ & 15618 & 24725 & 158.3 & 26.0 & 14.3 & 2241 & 9729 & 434.2 & 3.5 & 5.5 & 13377 & 14996 \\
\hline $\begin{array}{l}\text { Oilseeds and } \\
\text { oleaginous fruits }\end{array}$ & 7253 & 23755 & 327.5 & 46.6 & 29.4 & 362 & 1798 & 496.2 & 2.1 & 2.1 & 6891 & 21957 \\
\hline Fruit and vegetables & 7917 & 24483 & 309.3 & 10.8 & 10.5 & 8351 & 30702 & 367.6 & 10.5 & 12.9 & -435 & -6219 \\
\hline $\begin{array}{l}\text { Sugar and sugar } \\
\text { confectionery }\end{array}$ & 635 & 2276 & 358.5 & 3.1 & 4.7 & 1844 & 4712 & 255.6 & 8.8 & 9.4 & -1209 & -2436 \\
\hline Oils and fats & 2225 & 3254 & 146.2 & 8.4 & 3.4 & 1625 & 6212 & 382.3 & 6.1 & 6.4 & 600 & -2958 \\
\hline Total & 60615 & 141470 & 233.4 & 12.7 & 9.9 & 40624 & 130234 & 320.6 & 8.3 & 9.1 & 19991 & 11236 \\
\hline
\end{tabular}

Source: (UNCTAD, 2017), own calculations. 


\section{Comparative advantages of the EU and US in the world agri-food trade}

Based on the calculated RCA values, it may be concluded that in 1995-2015, the EU countries demonstrated revealed comparative advantages in the exports of products of animal origin ( $\mathrm{RCA}>1$; Table 2). It is noticeable that during the period under consideration, the EU has strengthened its competitive position as an exporter of less processed goods (livestock) while experiencing a decline in exports of products with a higher value added (meat, meat preparations, dairy products). However, an important observation is that after excluding the intra-EU trade from the total flows, declining comparative advantages were reported in the EU only with respect to exports of dairy products (RCA=1.78 in 1995-1997 and $\mathrm{RCA}=1.49$ in 2013-2015). In 1995-1997, the EU countries held a relatively small comparative advantage in the exports of sugar and sugar confectionery to third-country markets $(\mathrm{RCA}=1.29)$. In 2013-2015, they had a comparative advantage in the exports of livestock, cereals and preparations of cereals to non-EU countries ( $\mathrm{RCA}=1.09$ and $\mathrm{RCA}=1.08$, respectively).

Similar conclusions may be drawn from the analysis of Revealed Competitiveness indexes (RC) which take into consideration both the export and import performance of a country. According to this approach, a favourable competitive situation was recorded for cereals and preparations of cereals not only in relationships with non-EU countries but also with respect to total trade volumes (Table 2). Note also that as regards cereals and products of animal origin, the EU's competitive position, measured with the Vollrath's index, was deteriorating in the global market while getting stronger in third-country relationships. In the period under consideration, the US demonstrated high (though declining) comparative advantages in exports of cereals and preparations of cereals, oilseeds and oleaginous fruits ( $\mathrm{RCA}>1$ and $\mathrm{RC}>0$ ) while reporting an improvement of their competitive position in trade in meat products and dairy products.

Note that in 1995-2015, both the EU countries and the US reached high comparative advantages in trade in those assortment groups which corresponded to their highest shares in global exports and generated a high, consistently increasing positive trade balance. Similar conclusions may be formulated based on product mapping by comparative advantage level and by export specialisation degree made with the Widodo method (2009).

In 1995-2015, the EU countries reached comparative advantages and run export specialisation ( $\mathrm{RSCA}>0$ and $\mathrm{TBI}>0$ ) in world trade in livestock, meat, meat preparations and dairy products (Fig. 2). In 1995-1997 and 2013-2015, the exports of the above commodity groups provided the EU countries with a $64 \%$ and a $55 \%$ share, respectively, in global exports. The trade surplus of USD 26.8 billion reached in 2013-2015 was twice as high as the positive trade balance of the total agri-food sector (Table 1). In third-country markets, EU countries held the highest comparative advantages with respect to (and were a net exporter of) livestock, dairy products and cereal products (Fig. 3). An important erosion of their competitive position in third-country markets was observed for sugar and sugar confectionery which, in 1995-1997, were among products providing a high comparative advantage, a nearly $20 \%$ share in world's exports and a trade surplus of USD 1 billion, approximately. Meanwhile, in 2013-2015, together with horticultural products, oilseeds, oils and fats, they formed a group with no comparative advantages which contribute to the widening trade deficit $(\mathrm{RSCA}<0$ and $\mathrm{TBI}<0)$. Together, these four assortment groups absorbed over $40 \%$ of expenditure on foods imported from outside the EU, while generating barely around $17 \%$ of revenue from agri-food exports to third-country markets. 


\section{K. Pawlak}

The reason for the increasingly negative balance of the EU trade in oilseeds and oils of plant origin was the need to import them because many EU countries are not self-sufficient in these products. In turn, the status of net importer of fruit and vegetables was determined by highly intensive intra-industry flows resulting from the complementarity between imported goods and intra-EU production.

Table 2. An evaluation of the EU and US comparative advantages in world trade in agri-food products in 19951997 and 2013-2015

\begin{tabular}{|c|c|c|c|c|c|c|c|c|c|}
\hline \multirow{2}{*}{ Product group } & \multirow{2}{*}{$\begin{array}{l}\text { SITC } \\
\text { code }\end{array}$} & \multicolumn{4}{|c|}{$1995-1997$} & \multicolumn{4}{|c|}{ 2013-2015 } \\
\hline & & $\mathrm{RCA}$ & $\mathrm{RC}$ & RSCA & TBI & $\mathrm{RCA}$ & $\mathrm{RC}$ & RSCA & TBI \\
\hline \multicolumn{10}{|c|}{ EU in total } \\
\hline Live animals & 00 & 1.25 & 0.19 & 0.11 & 0.10 & 1.54 & 0.27 & 0.21 & 0.14 \\
\hline Meat and meat preparations & 01 & 1.26 & 0.14 & 0.12 & 0.08 & 1.19 & 0.07 & 0.08 & 0.07 \\
\hline Dairy products & 02 & 1.75 & 0.25 & 0.27 & 0.13 & 1.65 & 0.25 & 0.24 & 0.14 \\
\hline Cereals and preparations of cereals & 04 & 0.83 & 0.29 & -0.10 & 0.12 & 0.89 & 0.22 & -0.06 & 0.11 \\
\hline Oilseeds and oleaginous fruits & 22 & 0.25 & -1.41 & -0.59 & -0.63 & 0.28 & -0.76 & -0.57 & -0.38 \\
\hline Fruit and vegetables & 05 & 1.03 & -0.18 & 0.01 & -0.13 & 0.96 & -0.19 & -0.02 & -0.09 \\
\hline Sugar and sugar confectionery & 06 & 0.84 & 0.16 & -0.08 & 0.07 & 0.72 & -0.12 & -0.16 & -0.06 \\
\hline Oils and fats & 4 & 0.76 & -0.08 & -0.13 & -0.05 & 0.70 & -0.18 & -0.18 & -0.09 \\
\hline \multicolumn{10}{|c|}{ EU - third countries } \\
\hline Live animals & 00 & 0.88 & 0.76 & -0.06 & 0.28 & 1.09 & 2.10 & 0.04 & 0.76 \\
\hline Meat and meat preparations & 01 & 0.88 & 0.25 & -0.06 & 0.04 & 0.77 & 0.46 & -0.13 & 0.19 \\
\hline Dairy products & 02 & 1.78 & 1.29 & 0.28 & 0.51 & 1.49 & 2.70 & 0.20 & 0.86 \\
\hline Cereals and preparations of cereals & 04 & 0.97 & 0.99 & -0.02 & 0.36 & 1.08 & 1.02 & 0.04 & 0.41 \\
\hline Oilseeds and oleaginous fruits & 22 & 0.19 & -2.45 & -0.68 & -0.88 & 0.12 & -2.27 & -0.78 & -0.84 \\
\hline Fruit and vegetables & 05 & 0.61 & -0.79 & -0.24 & -0.48 & 0.62 & -0.85 & -0.24 & -0.46 \\
\hline Sugar and sugar confectionery & 06 & 1.29 & 0.55 & 0.13 & 0.17 & 0.56 & -0.23 & -0.28 & -0.18 \\
\hline Oils and fats & 4 & 0.85 & -0.11 & -0.08 & -0.15 & 0.63 & -0.57 & -0.23 & -0.34 \\
\hline \multicolumn{10}{|c|}{ The US } \\
\hline Live animals & 00 & 0.45 & -1.49 & -0.38 & -0.48 & 0.42 & -1.33 & -0.41 & -0.56 \\
\hline Meat and meat preparations & 01 & 1.09 & 0.52 & 0.04 & 0.45 & 1.26 & 0.59 & 0.12 & 0.34 \\
\hline Dairy products & 02 & 0.19 & -0.37 & -0.68 & 0.04 & 0.62 & 0.91 & -0.24 & 0.47 \\
\hline Cereals and preparations of cereals & 04 & 2.04 & 1.57 & 0.34 & 0.75 & 1.44 & 0.87 & 0.18 & 0.44 \\
\hline Oilseeds and oleaginous fruits & 22 & 3.66 & 2.65 & 0.57 & 0.90 & 2.98 & 2.56 & 0.50 & 0.86 \\
\hline Fruit and vegetables & 05 & 0.85 & -0.40 & -0.08 & -0.03 & 1.07 & -0.29 & 0.03 & -0.11 \\
\hline Sugar and sugar confectionery & 06 & 0.24 & -1.46 & -0.61 & -0.49 & 0.47 & -0.79 & -0.36 & -0.35 \\
\hline Oils and fats & 4 & 0.66 & -0.10 & -0.21 & 0.16 & 0.35 & -0.71 & -0.49 & -0.31 \\
\hline
\end{tabular}

Source: (UNCTAD, 2017), own calculations. 


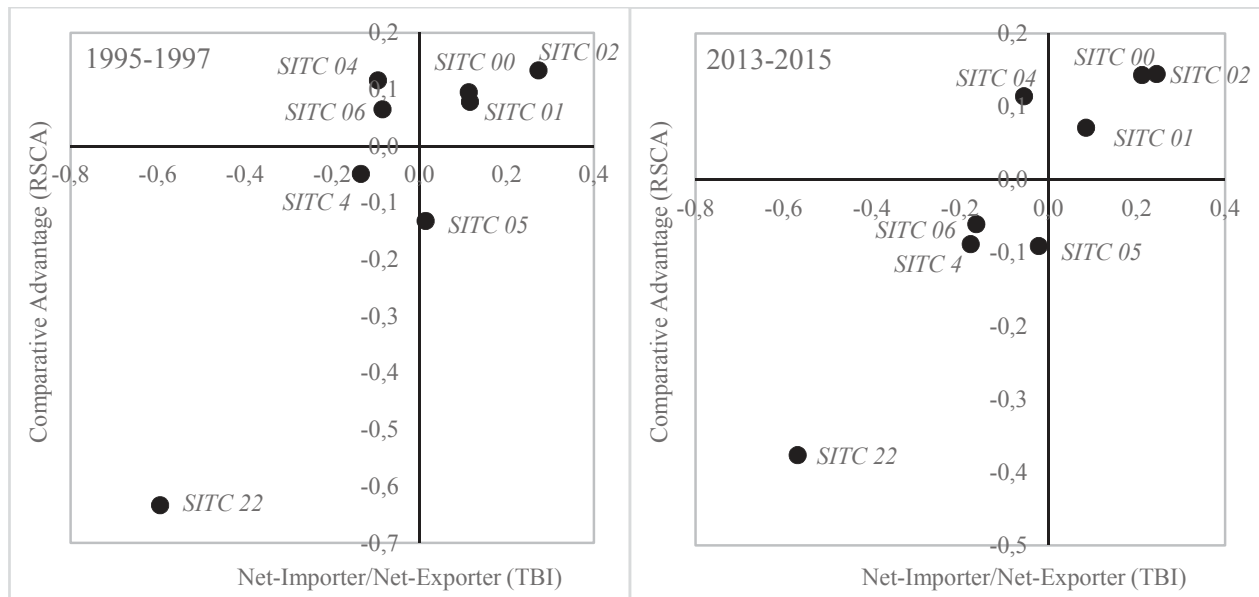

Fig. 2. Product mapping scheme for selected agri-food product groups exported from the EU by the level of comparative advantage and export specialisation in 1995-1997 and 2013-2015 (total trade, Widodo's method) Source: (UNCTAD, 2017), own calculations.

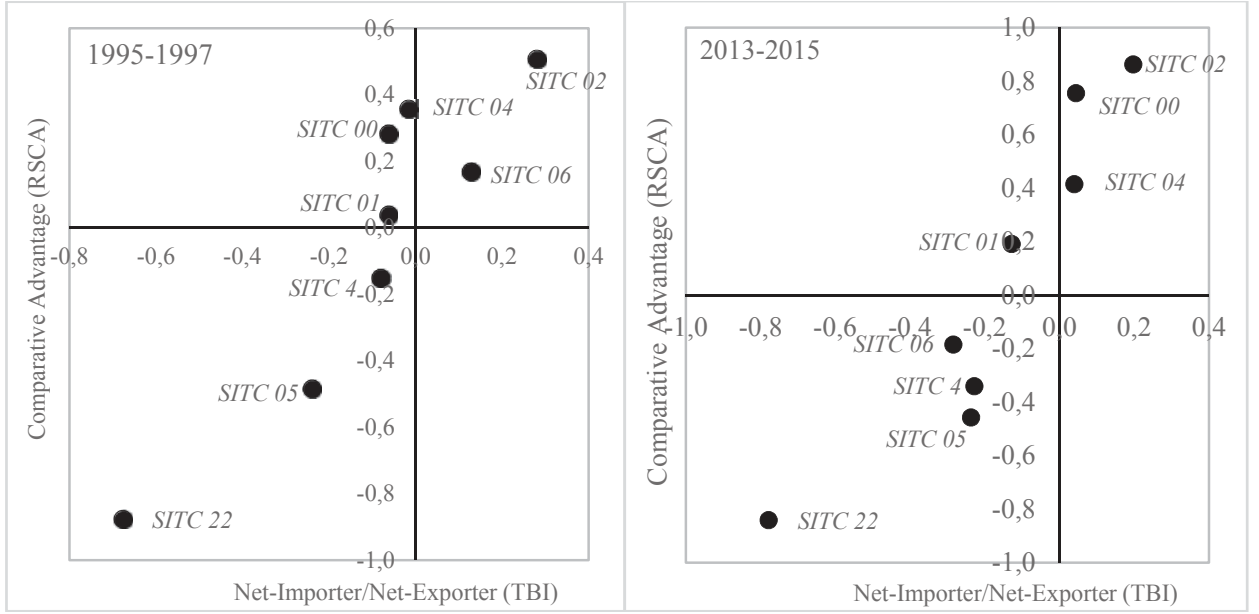

Fig. 3. Product mapping scheme for selected agri-food product groups exported from the EU by the level of comparative advantage and export specialisation in 1995-1997 and 2013-2015 (trade with third countries, Widodo's method)

Source: (UNCTAD, 2017), own calculations. 


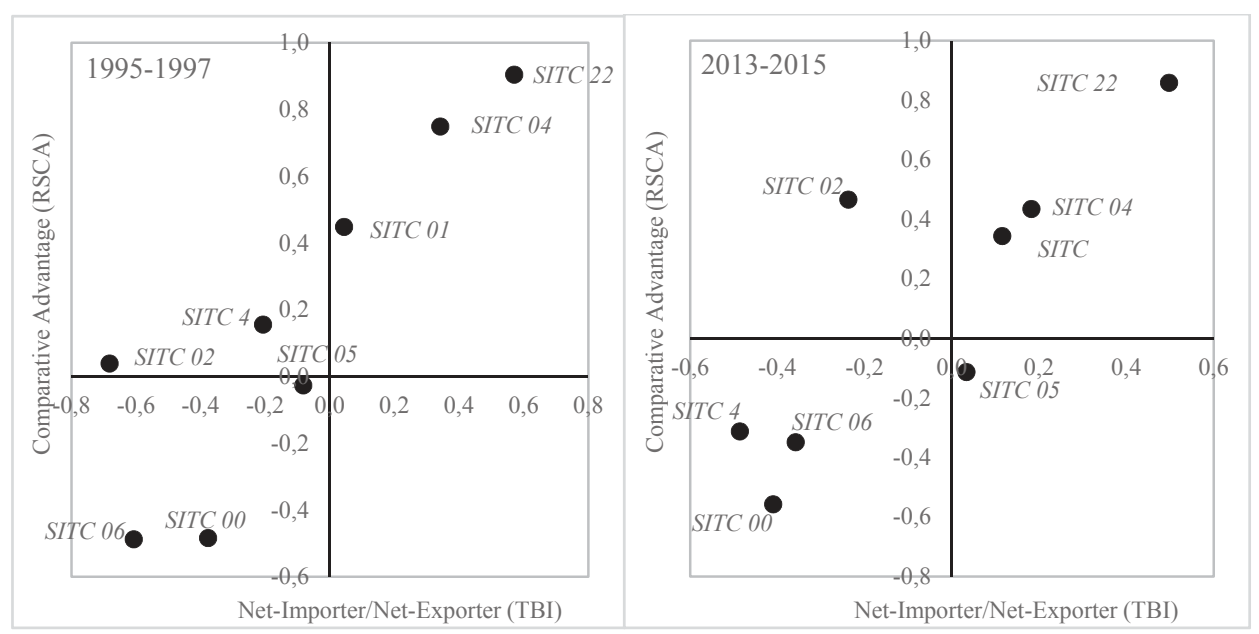

Fig. 4. Product mapping scheme for selected agri-food product groups exported from the US by the level of comparative advantage and export specialisation in 1995-1997 and 2013-2015 (Widodo's method)

Source: (UNCTAD, 2017), own calculations.

In the US, the highest comparative advantages (RSCA $>0)$ and the highest trade benefits reflected by the growing trade surplus in 1995-2015 (TBI $>0$ ) were observed for oilseeds, oleaginous fruits, cereals, cereal preparations and meat products (Fig. 4) which, in 2013-2015, accounted for nearly 47\% of total revenue from agri-food exports and generated a positive trade balance of around USD 46 billion (Tab. 1), i.e. four times more than the total agri-food trade balance. Throughout the period under consideration, no comparative advantages $(\mathrm{RSCA}<0)$ were reported for livestock, horticultural products and sugar confectionery exported from the US. In 2013-2015, this was also true for oils and fats. These circumstances (except for fruit and vegetables in 2013-2015) were not encouraging to engage into export specialisation in this field $(\mathrm{TBI}<0)$. However, importantly, in the last period under consideration, the exports of product groups with no comparative advantages (which strengthened the US role as a net importer) represented barely $5 \%$ of total agri-food exports.

\section{Concluding remarks}

The EU countries and the US are the largest players of world trade in agri-food products. Together, they accounted for approximately $48 \%$ of global food trade in mid2010s. In the last twenty years, their involvement in international exports and imports of agricultural products has reduced by approximately 9 percentage points and 7 percentage points, respectively. In 1995-2015, the EU countries held revealed comparative advantages in the global market as regards exports of products of animal origin whereas the exports of cereals, preparations of cereals, oilseeds, oleaginous fruits and meat products were the source of revealed comparative advantages for the US. It is noticeable that during the period under consideration, the EU has strengthened its competitive position as an exporter of less processed animal products (livestock) while experiencing a decline in exports of 
products with a higher value added, such as meat, meat preparations and dairy products which, in turn, were the source of increasingly higher comparative advantages for the US. In view of the above, it may be concluded that in the coming years these two sectors may prove to be the most sensitive ones to the increase of competitive pressure in the EU-US bilateral trade and in global trade flows, especially in light of the potential trade liberalisation.

It should be noted that both the EU countries and the US reached high comparative advantages in trade in those assortment groups which corresponded to their highest shares in global exports and generated a high, consistently increasing positive trade balance. Therefore, it may be concluded that their comparative advantages were the source of their favourable export specialisation profile, and the trade commodity structure in these countries has changed in accordance with the classical comparative costs principle.

\section{References}

Agriculture Canada. Task Force on Competitiveness in the Agri-Food Industry (1991). Growing Together: Report to Ministers of Agriculture. Ottawa: Agriculture Canada.

Anderson, K. (1990). China's Economic Growth, Changing Comparative Advantages and Agricultural Trade. Review of Marketing and Agricultural Economics, 58(1), 56-75.

Balassa, B. (1965). Trade Liberalisation and "Revealed" Comparative Advantage. The Manchester School, 33(2), 99-123. DOI: 10.1111/j.1467-9957.1965.tb00050.x.

Banterle, A. (2005). Competitiveness and Agri-Food Trade: An Empirical Analysis in the European Union. Paper presented at the 11th Congress of the European Association of Agricultural Economists, Copenhagen, Denmark, 24-27 August 2005, 1-13.

Banterle, A., Carraresi, L. (2007). Competitive performance analysis and European Union trade: The case of the prepared swine meat sector. Acta Agriculturae Scandinavica: Section C - Food Economics, 4(3), 159-172.

Benesova, I., Maitah, M., Smutka, L., Tomsik, K., Ishchukova, N. (2017). Perspectives of the Russian agricultural exports in terms of comparative advantage. Agricultural Economics - Czech, 63(7): 318-330. DOI 10.17221/344/2015-AGRICECON.

Bieńkowski, W. (1995). Reaganomika i jej wpływ na konkurencyjność gospodarki amerykańskiej. Warszawa: Wydawnictwo Naukowe PWN.

Bojnec, S. (2001). Trade and Revealed Comparative Advantage Measures. Regional and Central and East European Agricultural Trade. Eastern European Economics, 39(1), 72-98.

Casson, M. (1991). Global Research Strategy and International Competitiveness. Oxford: Basil Blackwell.

Czarny, E., Śledziewska, K. (2012). Międzynarodowa współpraca gospodarcza w warunkach kryzysu. Warszawa PWE.

Dalum, B., Laursen, K., Villumsen, G. (1998). Structural Change in OECD Export Specialisation Patterns: despecialisation and 'stickiness'. International Review of Applied Economics, 12(3), 423-443.

De Benedictis, L., Tamberi, M. (2002). A note on the Balassa Index of Revealed Comparative Advantage. Universita' Politecnica delle Marche Working Paper, 158. Accessed 11 October 2017 from: https://ideas. repec.org/p/anc/wpaper/158.html.

Ervani, E. (2013). Export and Import Performance of Indonesia's Agriculture Sector. Journal of Economics and Policy, 6(1), 54-63. DOI: 10.15294/jejak.v6i1.3748.

Hybel, J. (2002). Konkurencyjność polskich producentów owoców i warzyw w handlu zagranicznym. Roczniki Naukowe SERiA, 4(4), 53-57.

Ishchukova, N., Smutka, L. (2014): "Revealed" Comparative Advantage: Products Mapping of the Russian Agricultural Exports in Relation to Individual Regions. Acta Scientiarum Polonorum. Oeconomia, 13(1), 45-61.

JaeBin, A., Amiti, M., Weinstein, D.E. (2011). Trade Finance and the Great Trade Collapse. American Economic Review, 101(3), 298-302.

Kennedy, P.L., Harrison, R.W., Kalaitzandonakes, N.G., Peterson, H.Ch., Rindfuss, R.P. (1997). Perspectives on Evaluating Competitiveness in Agribusiness Industries. Agribusiness, 13(4), 385-392. 
Kim, D., Marion, B.W. (1997). Domestic Market Structure and Performance in Global Markets: Theory and Empirical Evidence from U.S. Food Manufacturing Industries. Review of Industrial Organization, 12(3), 335-354.

Krugman, P. (1994). Competitiveness: A Dangerous Obsession. Foreign Affairs, 73(2), 28-44.

Lafay, G. (1992). The Measurement of Revealed Comparative Advantages. In: M.G. Dagenais, P.A. Muet (eds.). International Trade Modeling (p. 209-234). London: Chapman \& Hill.

Landau, R. (1992). Technology, Capital Formation and U.S. Competitiveness. In: B.G. Hickman (ed.) International Productivity and Competitiveness (p. 299-325). New York: Oxford University Press.

Laursen, K. (1998). Revealed Comparative Advantage and the Alternatives as Measures of International Specialisation. DRUID Working Paper, 98-30.

Leishman, D., Menkhaus, D.J., Whipple, G.D. (1999). Revealed Comparative Advantage and the Measurement of International Competitiveness for Agricultural Commodities: An Empirical Analysis of Wool Exporters. Paper presented at Western Agricultural Economics Association Annual Meeting, Fargo, ND, 11-13 July 1999, 1-16.

Levchenko, A.A., Lewis, L.T., Tesar, L.L. (2010). The Collapse of International Trade During the 2008-2009 Crisis: In Search of the Smoking Gun. IMF Economic Review, 58(2), 214-253.

Pawlak, K. (2013). Międzynarodowa zdolność konkurencyjna sektora rolno-spożywczego krajów Unii Europejskiej. Rozprawy Naukowe, 448. Poznań: Wydawnictwo Uniwersytetu Przyrodniczego w Poznaniu.

Pawlak, K., Poczta, W. (2011). Międzynarodowy handel rolny. Teorie, konkurencyjność, scenariusze rozwoju. Warszawa: PWE.

Peterson, J. (1988). Export shares and revealed comparative advantage. A study of international travel. Applied Economics, 20(3), 351-365.

Pitts, E., Lagnevik, M. (1998). What determines food industry competitiveness? In: W.B. Traill, E. Pitts (eds.) Competitiveness in the food industry (p. 1-34). London: Blackie Academic \& Professional.

Porter, M.E. (1990). The Competitive Advantage of Nations. New York: The Free Press, A Division of Macmillan Inc.

Posłuszny, K. (2011). Konkurencyjność międzynarodowa jako miara skuteczności restrukturyzacji przemysłu. Ekonomia Menedżerska, 9, 49-61.

Reed, M.R. (2001). International Trade in Agricultural Products. Upper Saddle River, New Jersey: Prentice Hall.

Rynarzewski, T., Zielińska-Głębocka, A. (2006): Międzynarodowe stosunki gospodarcze. Teoria wymiany i polityki handlu międzynarodowego. Warszawa: Wydawnictwo Naukowe PWN.

Rytko, A. (2003). Środkowoeuropejskie Porozumienie Wolnego Handlu CEFTA jako studium rozwoju integracji europejskiej w sferze rolnictwa i gospodarki żywnościowej. Warszawa: Wydawnictwo SGGW.

Stanowisko Rady Strategii Społeczno-Gospodarczej przy Radzie Ministrów (1997). Międzynarodowa konkurencyjność gospodarki polskiej. In: J. Mujżel (ed.) Międzynarodowa konkurencyjność gospodarki polskiej. Raport nr 30. Warszawa: Rada Strategii Społeczno-Gospodarczej przy Radzie Ministrów.

UNCTAD, 2017. Data Center. Accessed 13 October 2017 from: http://unctadstat.unctad.org/wds/ReportFolders/ reportFolders.aspx?sCS_ChosenLang=en.

Van Duren, E., Martin, L., Westgren, R. (1991). Assessing the Competitiveness of Canada's Agrifood Industry. Canadian Journal of Agricultural Economics, 39(4), 727-738.

Vollrath, T. (1985). Dynamics of Comparative Advantage and the Resistance to Free Trade. Foreign Agricultural Economic Report, 214. Washington D.C: U.S. Department of Agriculture, Economic Research Service.

Vollrath, T.L. (1989). Competitiveness and Protection in World Agriculture. Agriculture Information Bulletin, 567. Washington D.C: U.S. Department of Agriculture, Economic Research Service.

Widodo, T. (2009). Comparative Advantage: Theory, Empirical Measures and Case Studies. Review of Economic and Business Studies, 4, 57-81.

Woś, A. (2001). Konkurencyjność wewnętrzna rolnictwa. Warszawa: IERiGŻ.

WTO. (2017). WTO Statistics Database. Accessed 4 October 2017 from: http://stat.wto.org/Home/WSDBHome. aspx ? Language $=\mathrm{E}$.

Wziątek-Kubiak, A. (2003). Konkurencyjność polskiego przemysłu. Warszawa: Dom Wydawniczy Bellona. 